\title{
Demokrat Parti Dönemi Kars'ta Sağlık Hizmetlerinde Yaşanan Gelişmeler
}

\author{
DOI: $10.26466 /$ opus.525480 \\ * \\ İlyas Topçư
}

*Dr. Öğr. Üyesi, Kafkas Üniversitesi, İktisadi ve İdari Bİlimler Fakültesi, Siyaset Bilimi ve Uluslararası İlişkiler Bölümü / Kars / Türkiye E-Posta: ilyastopcu@hotmail.com

ORCID: 0000-0002-9460-1127

\section{Öz}

Birinci Dünya Savaşı ve ardından Kurtuluş Savaşı sürecinin yaşandığı Anadolu coğrafyasında, diğger alanlarda olduğu gibi, sağlık alanında da çok ciddi sıkıntılar bulunmaktaydı. Yeni kurulan Türkiye Cumhuriyeti'nde üzerinde durulması gereken en önemli konuların başında da sağlık sektörü gelmekteydi. Cumhuriyetin ilanından sonra atılan adımlarla belirli bir noktaya kadar sorunlar giderilmeye çalışıldıysa da, İkinci Dünya Savaşı ve sonrasında halen daha salgın hastalıklar, çocuk ölümleri, hastane ve sağllk personeli sıkıntısı ülkenin önemli gündem başlıklarından bir tanesiydi. 7 Ocak 1946'da kurulan ve 1950-1960 yılları arasında ülke yönetiminde tek başına söz sahibi olan Demokrat Parti, on yıllık iktidar dönemi süresince să̆llk alanında önemli adımlar attı. Bu dönemde Sağ lık Bakanlığı'na ayrllan bütçe artışına paralel olarak, bir taraftan yeni hastaneler ve sağlık merkezleri açılırken, diğer taraftan da sağlık personeli açı̆̆ının kapatılması için çalışıldı. DP döneminde doğu illerine yapılan sağlık yatırımlarındaki artışın etkisi Kars'ta da hissedildi. Bu çalışma ile on yıllık DP iktidarı süresince Kars'ta sağlık alanında yaşanan gelişmeler aktarılmaya çalışılacaktır.

Anahtar Kelimeler: Demokrat Parti, Sağlık, Kars, Hastane, Sağlık Personeli. 


\title{
Developments in Health Care Services in The Democratic Party Era
}

\begin{abstract}
As in other areas, there were serious problems in the field of health in the Anatolia where the First World War and then the War of Independence were occurred. Health sector was one of the most important issues to be dwelled on in the newly founded Republic of Turkey. Although the problems were tried to be solved by the steps taken after the declaration of the Republic; outbreaks of epidemics, child mortality, the lack of hospital and medical staff were the most important agenda topics of the country during the Second World War and later. The Democratic Party, which was established on 7 January 1946 and had had a voice in the country's administration between 1950-1960, had took important steps in the field of health during its ten years of rule. In parallel with the increase in the budget allocated to the Ministry of Health in this period, both efforts were made to narrow the gap of medical staff, and new hospitals and health centers were opened. The effect of the increase in health expenditures in the DP period to eastern provinces had been also felt in Kars. In this study, the developments in the field of health in Kars during the ten-year DP administration will be tried to be conveyed.
\end{abstract}

Keywords: Democratic Party, Health, Kars, Hospital, Medical Stuff 


\section{Giriş}

İnsan, yaşadığı ortam ile sürekli etkileşim içinde bulunduğundan dolayı, ortamı oluşturan tüm unsurlar, sağlık üzerinde belirleyici bir role sahiptir. Doğal ortama, savaşların yıpratıcı etkileri de eklenince şartlar daha da zor bir hale gelir. Devletlerin varlıklarını sürdürebilmeleri için, insan ve toplumun sağlıklı olması ve bu durumun sürdürülebilmesi gereklidir. Aksi taktirde, devletlerin istikbali tehlikeye girecektir. Bu yüzden devletler tarih boyunca, halk sağlığı konusuna önem vermiş ve bu noktada birçok tedbirler alarak, düzenlemeler yapmışlardır. Birinci Dünya Savaşı ve ardından 1919-1922 Millî Mücadele yılları sürecinden geçen Türkiye, her alanda çok büyük yıkımlara maruz kalmış, müthiş bir yoksulluk ve sefalete sürüklenmiştir. Bu nedenle, TBMM hükümetinin ilk icraatları arasında bir sağlık bakanlığının kurulması gelmektedir (Gümüşçü, 2003, s.127).

1923'e kadar zamanın koşulları içeresinde yürütülen Bakanlık çalışmaları; ülkenin sağlık koşullarını düzeltmek, kişi ve toplum sağlı̆̆ına zarar veren unsurlarla savaşmak, gelecek nesillerin sağlıklı olarak yetiştirilmesini sağlamak amacıyla hızla ilerlemeye yönelmiş ve yeni bir statü ile hizmet alanı, merkez ve taşra örgütü genişletilmiştir. Nüfusun çoğunluğunu teşkil eden ilçe merkezlerindeki halkın, sağlık hizmetlerinden yararlandırılması için 1924 'de 150 ve 1936 'da 20 ilçe merkezinde Muayene ve Tedavi Evleri açılmıştır. Daha sonra sağlık merkezlerine ve sağlık ocaklarına dönüştürülmüştür (80 Yılda Tedavi Hizmetleri, 2004). 1923 yılında Türkiye Cumhuriyeti kurulduğunda 950 yataklı 3 devlet hastanesi, 635 yataklı 6 belediye hastanesi, 4.520 yataklı 45 özel idare hastanesi, 2.402 yataklı 32 özel yabancı ve azınlık hastanesi olmak üzere toplam 6.437 hasta yatağ ve 86 hastane bulunuyordu (80 Yılda Tedavi Hizmetleri, 2004). Ayrıca toplamda 554 hekim, 69 eczacı, 4 hemşire, 560 sağlık memuru ve 136 ebe mevcuttu (https://www.saglik.gov.tr 2019).

Cumhuriyetin onuncu yılında ülkedeki doktor sayısı 1.211'e, sağlık memuru 1.306'ya, hemşire 257'ye, ebe sayısı da 402'ye yükseldi. 1929-1933 yılları arasında yatılı tıp öğrenci yurdundan toplam 137, küçük sıhhat memuru okullarından toplam 139 ve Şişli Çocuk Hastanesi'ndeki yatılı ebe öğrenci yurdundan 77 kişi mezun oldu. Söz konusu dönemde ülkedeki eczacı sayısı 121'dir. Bir doktora 12.710, hemşireye 59.891, sıhhat 
memuruna 11.786, ebeye 38.289 kişi düşmektedir. Bakanlığa bağlı hastane ve dispanser sayısı 339 olup, buralardaki toplam yatak sayısı 9.187'dir. Harcamaları genel bütçeye ait 9 doğumevi olup bunların toplam yatak sayıs1 205'tir. Bunlar; Ankara, Konya, Malatya, Kars, Erzurum, Van ve Balıkesir'de bulunmaktadırlar. 1940'da ülke genelinde 2.387 olan hekim say1sı, 1950'de 6.845'e, 340 eczac1 980'e, 1.493 sağlık teknisyeni 4.018'e, 405 hemşire 737'e, 616 ebe sayısı da 1.285'e yükseldi (Ak, 2002).

İkinci Dünya Savaşından sonra bütün dünya ülkelerinde değişen sosyal yaşantı ve ekonomik güçlükler birçok sağlık sorunlarını da beraberinde getirdi. Diğer ülkeler gibi Türkiye' de de sağlık hizmetlerinin rasyonel ve planlı bir şekilde uygulanması için çalışmalar yapıldı. Kasım 1946 'da Yüksek Sağlık Şurası'nın onayından geçen Birinci On Yıllık Milli Sağlık Planı bunların ilkidir ${ }^{1}$ Bu planda Türkiye 7 ana bölgeye ayrıldı ve her bölgede 500 yataklı birer hastane açılması kararlaştırıldı. Var olan hastanelerin ise daha iyi hizmet verecek şekilde düzenlenmesi, her bölgede 300 yataklı çocuk hastaneleri, çocuk bakımevleri, 200 yataklı doğumevleri açılması, yaşlı ve düşkünler için yurtlar oluşturulması, çocuk ölümlerinin asgariye indirilmesi, engelli vatandaşlara güç kazandıracak kurumların açılması, tropikal hastalıklar için enstitüler kurulması, sağlık personeli yetiştirecek okullar açılması, Merkez Hıfzıssıhha Kurumu'nun geliştirilmesi ve ilaç sanayinde dışa bağımlılığın önlenmesi, sıtmalı bölgelerdeki bataklıkların havadan ilaçlanması ve ayrıca özel bir kanunla hastalık sigortası için "Sağlık Sandıkları" kurulması planlandı. Ancak geçen süre zarfında plan, gereği gibi uygulanamadı. Sağlık merkezlerinin bir bölümü yapılmısssa da, bunlar etkili hizmet vermekten uzaktı ve uygulama ilçelerden öteye yaygınlaştırılamadı (Ak, 2002).

\section{Demokrat Parti Dönemi Türkiye'de Sağlık Politikaları}

14 Mayıs 1950 seçimleriyle beraber 27 yıllık CHP iktidarının ardından

\footnotetext{
1 “Milli Sağlık Planı'nda köy ve köylülerimizi sağlık teşkilatına kavuşturmak ilkesi çerçevesinde, her 40 köy için 10 yatakı bir sağık merkezi kurularak tedavi edici hekimlikle koruyucu sağlık hizmetlerinin birlikte verilmesi sağlanmaya çalışılmıştır. Bu merkezlere iki hekim, bir sağlık memuru, bir ebe ve bir ziyaretçi hemşire ile onar köylük gruplarda çalışacak köy ebesi ve köy sağlık memurları atanmasına çalışıılı. 1945 yılında 8 olan Sağıık Merkezi sayısı 1950 yılında 22'ye, 1955'de 181'e, 1960 yılında 283'e ulaşmıştır" (80 Yılda Tedavi Hizmetleri, 2004: 6, Sağlık Bakanlığı, Stratejik Plan 2010-2014).
} 
Demokrat Parti iktidara geldi. 1950-1960 yılları arasında Demokrat Parti iktidarında Türkiye'de uygulanan iktisat politikasında, iç ve dış ticarete iç serbest piyasa koşullarının hakim kılınması, özel girişimciliğin her platformda desteklenmesi ve geliştirilmesi, devletin özellikle sanayi alanındaki kamu yatırımlarının sınırlandırılması, tarımda makineleşme ve karayolu ulaşımına öncelik ve önem verilmesi, kamu yatırımlarının alt yapı alanına yöneltilmesi ve yabancı yatırımların özendirilmesi ön plana çımaktadır (Tokatlığlu ve Öztürk, 2008).

Sağlık konusu ise Demokrat Parti'nin 1949 yılındaki kongresinde kabul edilen tüzük ve programın 87. maddesi ile ele alınmaktadır. Bu maddeye göre: "Nüfusumuzun ve istihsal kudretimizin çoğalması davasında büyük bir amil olan umumi sağllk işlerimiz, artan bir hızla ve planla yürütülmek ihtiyacındadır. Bunun için, bütçeden yeter tahsisat ayrılmasını, sıtma başta olmak üzere millî bünyeyi kemiren bütün hastaliklarla esaslı surette mücadele imkân ve vasıtalarının sağlanmasın ve bu maksatla, ilgili bakanlıklar ile de işbirliği yapılmasın, partimiz, memleketin en büyük ihtiyaçlarından sayar (DP Tüzük ve Program1, 1949)" denilmektedir.

$\mathrm{Bu}$ doğrultuda, 1950 'de 1.487.208.563 lira olan devlet bütçesinin \%4.07'si yani 60.615.522 lirası Sağlık Bakanlığı'na ayrıldı. 1955'te 2.940.727.278 liralık devlet bütçesinden 152.463.881 lira, 1960'ta da 7.266.965.000 lira olan devlet bütçesinden 382.762.029 lira Sağlık Bakanlığı'na ayrıldı. Sağlık Bakanlığı bütçesinin devlet bütçesine oranı 1955 'te \%5.18 ve 1960'ta \%5.27 olarak gerçekleşti (Ak, 2002).

Demokrat Parti yönetimi Ankara ve İstanbul gibi büyük kentlerdeki hastanelere yığılmayı önlemek ve halkın ihtiyacı olan sağlık hizmetini daha yakınından sunabilmek adına tüm kentlerde ve büyük ilçelerde hastane açma politikası izledi. Diğer taraftan, daha liberal politikalar izleyerek sağlık alanında da özel sektörün gelişimini teşvik etmeye çalıştı (Kasapoğlu, 2016).

1923 yılında Türkiye' de sadece 86 hastane ve 554 doktor bulunuyordu. O dönemdeki adıyla "memleket hastanelerinin" sayısı az ve imkanları da kısıtliydı. Cumhuriyet döneminde yapılan yatırımlar ile beraber 19501960 yılları arasında Sağlık ve Sosyal Yardım Bakanlığı'na (SSYB) bağlı yataklı tedavi kurumlarının durumu şöyledir: 1950'de 118 olan toplam kurum sayıs1 1960'ta 442'ye ve toplam yatak sayıs1 14.581 'den $32.398^{\prime}$ e, devlet hastanesi $41^{\prime}$ den $94^{\prime}$ e ve yatakların sayıs $7.571^{\prime}$ den 14.946 'ya, 
sağlik merkezi $22^{\prime}$ den 283 'e ve yatak sayıları $220^{\prime}$ den $3.527^{\prime}$ ye; doğumevi sayısı $16^{\prime}$ dan $20^{\prime}$ ye ve yatak sayıları $710^{\prime}$ dan $2.095^{\prime}$ e yükseldi (DİGM, 1953, DİGM, 1960-62). Göğüs hastalıkları hastanesi sayısı 18'den 31'e ve yatak sayıları $2.107^{\prime}$ den $6.205^{\prime} \mathrm{e}$, ruh ve sinir hastalıkları yatak sayıları 2.800 'den 3.460 'a, kemik hastalıkları hastanesi 1'den 4'e ve yatak sayıları 150 'den $925^{\prime} \mathrm{e}, 1$ cüzzam hastanesinde yatak sayısı 200 'den 2.502 'ye çıkartıldı. Trahom hastanesi $16^{\prime}$ dan 6'ya ve yatak sayllar $225^{\prime}$ ten $150^{\prime}$ ye ve kuduz hastanesi 3'ten 1'e ve yatak sayısı 225 'ten 50'ye düsstü Ak, 2002). 1950 yılında yüz bin kişiye 9 yatak düsserken, 1960 yılına gelindiğinde bu oran 16,6'ya çıktı (SB Stratejik Plan 2010-2014).

\section{Demokrat Parti Dönemine Kadar Kars'ta Sağlık Hizmetleri}

1888 yılında Kars'ta 6 sivil, 27 askeri doktor ve 3 veteriner, 1889 yılında ise 4'ü şehir merkezinde olmak üzere toplam 10 doktor vardı. Aynı dönemde biri kadın iki diş doktoru, ayrıca 17 sağlık memuru, 8 ebe ve 9 çiçek aşıcısı vard1. 1912 yılına gelindiğinde vilayetteki askeri doktorlar hariç sivil doktorların sayısı vilayet merkezinde 5, sancaklarda 12 olmak üzere toplam 17 kişiye ulaşmıştır. Yine iki diş doktoru, 48 sağlık memuru ve ebe görev yapmaktadır. Hastanelerin sayısı 8'i köylerde olmak üzere 10'a ulaşmıştı. 8 sağlık ocağı vardır ve buralarda 115.345 hasta muayene olmuştur. Kars'ta iki, Ardahan, Kağızman, Sarıkamış ve Oltu'da birer eczane vardır (Badem, 2010).

Cumhuriyetin devraldığı miras içerisinde Doğu Anadolu'da yaşanan sağlık sorunları ayrı bir yer tutmaktaydı. Bu durum bölgedeki iller hakkında düzenlenen raporlarla da dile getirilmekteydi. Bununla birlikte beslenme bozukluğu ve koruyucu hizmetlerin yokluğuna dayalı sağlık sorunları o dönemde yurdun büyük bölümünde yoğun biçimde yaşanmaktaydı. Bazen tek bir ilacın ithali problem oluyor ve siyasi tartışmaları doğurabiliyordu².

Kars'ta Cumhuriyetin ilanından sonra sağlık alanında ihtiyaçların giderilebilmesi için çalışmalar yapılmaya başlandı. Tuzluca ve Iğdır ilçelerinin de Kars'a bağlanmasıyla toplamda on ilçeli olan Kars'ta hükümet

\footnotetext{
2 "DP iktidarının ilk yıllarında Eylül 1951'de verem tedavisinde kullanılan "Streptomycine" adlı ilacın piyasada bulunmaması üzerine dönemin Sağlık ve Sosyal Yardım Bakanı radyoda oldukça uzun ve detaylı bir konuşma yapmak zorunda kalmıştır" (Aşgın, 2000, s.166).
} 
doktoru sayısı 3'e yükseldi. Genel denkliğe bağlı 10'u kadın, 10'u da çocuk hastalıklarıyla ilgili 20 yataklı doğum ve çocuk bakımevi 1929 yılının sonlarında açıldı (BCA, 030.10.65.433.3.1).

796 sayılı kanun hükümleri gereğince Kars'ta 250 yataklı hastane bulunması gerekirken, 1932 yılında 50 yataklı olan memleket hastanesi 1933 ve 34 yılında 25 yatağa indirildi. 1935 bütçe görüşmelerinde 25 yatağın Kars'ın ihtiyaçlarını karşılayamadığını, hastaların hastane kapılarında beklediğini gören il genel kurulu üyelerince yatak sayısı, 40' 1 parasız 10'u paralı olmak üzere 50 yatağa çıkarıldıysa da hastane kadrosu daimi üyelerinin verdiği kararla yeniden 25 indirildi³ ${ }^{3} 1935$ yılında yeni atanan beş doktorla ilçelerin doktor ihtiyacı karşılanmaya çalışıldı. Aynı yıl Arpaçay ve Çıldır'da birer dispanser açılarak çalışmalara başlandı.

1940 yılına gelindiğinde Kars'ta iki hastane hizmet vermekteydi. Birisi 60 yatak kapasiteli Memleket Hastanesi, diğeri de 20 yatak kapasiteli Doğum Evi'dir. Hastane, Dahiliye (25 yatakl1), Hariciye (25 yatakl1), ve Zührevi Hastalıklar (10 yataklı) olmak üzere 3 servisle hizmet vermekteydi (Ural, 2006).

Cumhuriyet döneminde yapılan yatırımlara ek olarak, 1946-1960 döneminin başlarında doğu illerinde yapılan kamu harcamaları genel ortalamanın üzerinde gerçekleşti. Buna göre, 1946-1950 döneminde Sağlık Bakanlığı'nca Kars'a yapılan kamu harcamaları 1.026.378.34 TL iken, bu rakam 1951-1955 döneminde 3.167.629.20 TL'ye, 1956-1960 döneminde de 9.148.339.24 TL'ye yükseldi. 1946'da başlayan artış, 1956-1960 arası dönemde üç katına yükseldi. 1946-1950 döneminde Kars' ta kişi başına düşen sağlik harcaması 2.69 TL iken, 1951-1955 döneminde ${ }^{4}$ bu rakam 7.72 TL'ye ve en çok harcamanın yapıldığ $1956-60$ yılında ise 18.75 TL'ye yükseldi (Aşgin, 2000, s.167-170).

\footnotetext{
${ }^{3}$ Ülkede zührevi hastalıkların günden güne artması sebebiyle frengi ve belsoğukluğuna tutulan hastaların, hastalıklarını halka bulaştırmaması için, 15 Temmuz 1935 tarihinden itibaren beş yatak açıldı (BCA, 030.10.65.433.3.1.).

${ }^{4}$ Kars Valisi Niyazi Akı́nın 15 Nisan 1952 tarihindeki açıklamalarına göre söz konusu yıl için Sağlık Bakanlığı'ndan Kars hastanesine ayrılan yardım miktarı 48.300 liradır. Ayrıca bu demecinde Vali, aynı yıl içerisinde Kars'ta 50 yataklı bir verem hastanesinin açılacağını ve buraya yeni doktorlar tayin edileceğini belirtmiştir (Ekinci Gazetesi, 15 Nisan 1952).
} 
1946-1960 Yılları Arası Kars'ta Sağlık Hizmetleri

\section{Hastaneler ve Sağlık Merkezleri}

1940 yılına gelindiğinde Kars'ta iki hastanenin hizmet verdiğini, birisinin 60 yatak kapasiteli Memleket Hastanesi, diğerinin de 20 yatak kapasiteli Doğum Evi olduğu önceden belirtilmişti. Kars'ın tek sivil hastanesi olan memleket hastanesine 1949 yılının sonlarına doğru ilave yapıldı. Ordu Caddesi'nin Yusufpaşa Mahallesi semtinde olan bu hastanenin batı yanına ve kayabaşı kısmına yüz bin liradan fazla paraya üç katlı yeni bina ilave edildi. Döşemesi kısmen beton ve kısmen ahşap olan bu yeni bina 50 yataklı olacak şekilde tasarlandı. Röntgen ve bakteriyoloji servislerinin de yapılması düşünüldü. Bu yeni binanın su, kalorifer ve elektrik tesisatı için lazım olan 90.000 liranın 1950 yılı bütçesine konularak Özel İdareden temin edilmesi düşünülüyordu. Eldeki imkanlara göre o dönem için iyi çalışan memleket hastanesinde tabip kadrosu tamamsa da eczacı ve başhemşire ile birde hemşire ihtiyacı vardı. Bakanlıktan gelen emirde 60 yataklı olan eski binada en az 10 yataklı tüberküloz servisi açılması istenmekteydi. Yeni binada fenni bir şekilde röntgen yeri hazırlanırken, 40.000 liralık bir cihazın temini düşünülüyordu. Son kararlara göre bu hastanede 1949 yılı itibariyle ikinci sınıf yer için günde 5, üçüncü sınıf yer içinse günde 3 lira ücret alınmaktaydı. 1949 yılının başından Eylül ayına kadar ancak 5.000 lira para alınabilmişken, buna karşılık hastanenin yıllık masrafı 82.000 liraydı. Yeni binanın ikmal ve açılışı ile 110 yataklı ve röntgenli olacak hastane ile Kars halkının birçok sıkıntısı giderilirken, röntgen için Erzurum'a gitmeye gerek kalmıyordu (Kars Gazetesi, 24 Eylül 1949).

Yıllardan beri 60 yataklık kapasitesiyle Kars halkının sağlık sorunlarına çare bulmaya çalışan Memleket Hastanesi gittikçe artan müracaatlar karşısında ${ }^{5}$ büyük bir yatak sıkıntısına maruz kaldığı için, yeni servisler ilavesiyle yatak adedinin tezyidi bir zaruret halini aldı. 1953 yılından itibaren dört tedavi servisi ilavesiyle yatak sayısı 120'ye çıartıldı (Ekinci Gazetesi, 14 Ocak 1954). Ayrıca 1 Mayıs 1953 tarihinde Memleket Hastanesinin bitişiğinde yapılan yeni bir pavyonda bir verem hastanesi

${ }^{5}$ Kars memleket hastanesinde 1950 yılında 1378 kişi, 1951 yılında 1973 kişi ve 1952 yılının ilk 11 ayında 2281 kişi yatarak tedavi edildi (Birlik Gazetesi, 13 Aralık 1952). 
tesis edildi. Müstakil bir hastane olarak faaliyete geçen bu sağlık müessesesi faydalı çalışmalarıyla kısa zamanda halkın sevgi ve itimadını kazandı. İntizamı, temizliği ve yeni tesisleriyle 1954 yılında şehrin en modern hastanesi konumundaydı (Kars Gazetesi, 29 Eylül 1954). Kars Memleket Hastanesi, Mart 1954'ten itibaren Devlet Hastanesi haline getirildi. Bu münasebetle hastanenin sağlık personeli kadrosu takviye edildi. Bu bağlamda hastaneye bir göz hekimi kadrosu da verildi ve göz hastalıkları mütehassısı Dr. Cemaleddin Arıman Kars'a gelerek görevine başladı (Kars Gazetesi, 12 Nisan 1954).

1955 yılı içerisinde 14.000 lira Devlet Hastanesinin bazı tamir işleri için vilayet emrine gönderildi (Ekinci Gazetesi, 18 Mayıs 1955). 1956 yılında Sağlık ve Sosyal Yardım Bakanlığı tarafından Kars'ta bir hastane inşası hususunda vaatte bulunulduğu ve teşebbüse geçileceğine dair açıllama valilik tarafından Mayıs ayında yapıldı. Sağlık Bakanlığından gelen Yüksek Mimar Edip Erbil, vali, belediye başkanı, sağlık müdürü, bayındırlık müdürü, hastane başhekimi ve belediye mühendisi ile birlikte hastanenin yapılacağı sahanın şehir imar durumu da nazara alınarak tetkikler yaptı. O dönem ortaokulun bulunduğu yer civarı ile stadyum yanındaki beden terbiyesine ait boş arsa yeri üzerinde duruldu. Bu yerlerin arsa ve imar vaziyeti tespit edildi. Hastane, doğumevini de içine alacak ve Kars'ın bütün sağlık ihtiyacını karşılayacak şekilde düşünülmekteydi (Kars Gazetesi, 13 Ağustos 1956).

Kars Devlet Hastanesi'nin zaruri ihtiyacı olan kalorifer şebekesinin yaptırılması hususunda Kars Valisi Hilmi Dağcıŏ̆lu'nun üç ay boyunca Bayındırlık Bakanlığı ile yaptığı temaslar neticesinde 600.000 liralık kalorifer tesis projesi hazırlandı. Erzurum'dan gelen mütehassıs tarafından keşifleri yapılarak projesi hazırlanan tesisatın ihalesi için Nafia Vekâletine durum 25.04.1959 tarih ve 1205 sayılı yazı ile bildirildi. Bu sayede, her sene 80 ila 100 sobanın yanmasıyla ısınan hastanenin çok büyük bir sıkıntısının giderilmesi noktasında önemli bir adım atıldı (Demokrat Kars Gazetesi, 9 Mayıs 1959).

Nüfusu 400.000'i bulan Kars'ın Doğum ve Çocuk Bakımevinde 1950 yılında, 2 mütehassıs doktor, 1 ebe, 6 hastabakıcı ve 6 kadın hademe vardır. 10 nisaiye, 10 doğum ve 10 da çocuk için olmak üzere buranın yatak sayısı toplamda 30'a ulaşmıştı. Baştabip Dr. Cavit Başar çocuk hastalıkları mütehassısıdır. 1949 yılı zarfında yalnız doğum kısmında 455 
hasta yatarken, bunlardan 62'sine müdahale edilip, 239'u normal doğum yaparken, 2'si de ne yazık ki öldü. 1950 yılının ilk beş ayı içerisinde de 251 hasta yatarken, bunlardan 97'si müdahale ve ameliyat gördü, 111'i normal doğum yaptı, kurtarılamayacak halde gelen 2 kişi de vefat etti (Kars Gazetesi, 1 Temmuz 1950). Kars doğum ve çocuk bakımevinde 1952 yılında 1.139 hasta muayene edildi, 819 hasta ise kliniğe yatırıldı. Bunların arasından 3 kişi vefat etti (Ekinci Gazetesi, 17 Şubat 1953). ${ }^{6}$

DP döneminde ayrıca büyük sıkıntılar içerisinde çalışmalarına devam eden hastanelerin millete faydalı olabilmesi için Sağlık Bakanlığı tarafından geniş çaplı 1slahatlara girişildi (Birlik Gazetesi, 21 Kasım 1952). Bu doğrultuda 27.09.1952 tarihi itibariyle Iğdır Hastanesi sağlık merkezine dönüştürüldü (Birlik Gazetesi, 13 Aralık 1952). Özel idarenin dar bütçesiyle bin bir müşkülat içerisinde faaliyetlerini idameye gayret ettirilen Iğdır Hastanesi daha verimli bir işleyiş̧e kavuşturulmak gayesiyle bakanlık teşkilatı içerisine alındı (Birlik Gazetesi, 21 Kasım 1952). Ertesi yıl Sıhhat ve İçtimai Muavenet Vekaleti'nin köylüyü doktora kavuşturma kararının bir neticesi olarak Kars'ta ilk defa Iğdır'ın Başköy nahiyesine bir hükümet doktoru tayin edildi (Ekinci Gazetesi, 28 Şubat 1953).

Demokrat Parti iktidarının umumi sağlık bahsinde her kazanın bir sağlık merkezine kavuşturulması icraatının bir adımı olarak 1953'te Ardahan'da hazırlıkları tamamlanmış olan sağlık merkezinin açılışı Kars'tan gelen Vali Niyazi Akı'nın başkanlık ettiği kalabalık huzurunda törenle yapıldı (Kars Gazetesi, 23 Mayıs 1953). Tuzluca da bu mezkur plana dahil edildi ve 1954 yılında diğer kazalarda olduğu gibi burada da bir sağlık merkezi açılması kararlaştırıldı. Bunun için gerekli hazırlıkların ikmali hususu Kars Valiliği'ne tebliğ edildi (Ekinci Gazetesi, 14 Ocak 1954). 8 Temmuz 1954 tarihinde hazırlıkların tamamlanmasıyla sağlık merkezinin temeli kurban kesilerek atıldı (Ekinci Gazetesi, 8 Temmuz 1954). 1 Haziran 1956 tarihinde de 10 yataklı Arpaçay sağlık binası hizmete açıldı (Kars Gazetesi, 4 Haziran 1956).

Sağlık ve Sosyal Yardım Bakanlığının kurmakta olduğu tesislerin yansıra, Kızılay Genel Merkezi de 1952 yılında, yurdun muhtelif bölgelerinde ve bu bağlamda Posof, Çıldır ve Iğdır ilçelerinde yirmişer yataklı

\footnotetext{
${ }^{6} 1955$ yılında Sıhhat ve içtimai Muavenet Vekâleti, ihtiyacı karşılamak ve daha faydalı olmak fikri ile Kars Doğum ve Çocuk Bakımevine 10 yatak ilavesini kabul etti ve bu husustaki muvafakat ilgililere bildirildi (Ekinci Gazetesi, 8 Nisan 1955).
} 
birer sağlık merkezi kurma kararını verdi. Genel merkez idare kurulunun yaptığı toplantıda bu iş için 4.000 .000 lira tahsis edildi ve inşaata hemen başlanarak yılsonuna kadar muhakkak tamamlanması için de karar alındı. Genel merkez tarafindan ayrıca tesisler ikmal edildikten sonra bu tesislerin sağlık ve Sosyal Yardım Bakanlığı emrine verilmesi kararı da alındı (Kars Gazetesi, 4 Mart 1952).

Bir taraftan kaza ve nahiyelere sıhhat merkezleri açılması için çalışmalar yapılırken diğer taraftan da henüz yeterli derecede hastane ve sağlık merkezi olmayan yerlerde sağlık taraması yapılması için genel merkezden Kızılay sağlık ekibi gönderildi. 10 Temmuz 1958 tarihinde Kars'a gelen Kızılay ekibi 11 Temmuz'da Posof'a gitti. Bu sağlık ekibi kadrosunda: Dr. Mehmet Kengerli, Baş. Tbb. İbrahim Badal, Cildiyeci Dr. Nurhan Aydınalp, intaniye(enfeksiyon hastalıkları) Dr. Haydar Kulel, Fizik Tedavi Teknisyeni Necati Turasan, hemşireler Nimet Kaya, Yıldız Kaldar, Şahver Balabanoğlu ve Zahide Sarığlu bulunmaktaydı (Demokrat Kars Gazetesi, 11 Temmuz 1958).

Tablo 1. 1946-1960 Yilları Arasında Kars'ta Ayakta ve Yatarak Tedavi Görenler ${ }^{7}$

\begin{tabular}{cccccc}
\hline Yillar & $\begin{array}{c}\text { Hastane } \\
\text { Sayıs }\end{array}$ & $\begin{array}{c}\text { Yatak } \\
\text { Sayıs }\end{array}$ & $\begin{array}{c}\text { Yatakta Te- } \\
\text { davi Gören }\end{array}$ & $\begin{array}{c}\text { Ayakta Te- } \\
\text { davi Gören }\end{array}$ & Toplam \\
\hline $\mathbf{1 9 4 6}$ & 2 & 80 & 1551 & 9850 & 11401 \\
$\mathbf{1 9 4 7}$ & 2 & 80 & 1600 & 9126 & 10726 \\
$\mathbf{1 9 4 8}$ & 2 & 80 & 2007 & 12542 & 14549 \\
$\mathbf{1 9 4 9}$ & 2 & 90 & 1931 & 6887 & 8818 \\
$\mathbf{1 9 5 0}$ & 3 & 115 & 2224 & 6949 & 9173 \\
$\mathbf{1 9 5 1}$ & 3 & 115 & 2207 & 10342 & 13549 \\
$\mathbf{1 9 5 2}$ & 5 & 170 & 3803 & 15027 & 18830 \\
$\mathbf{1 9 5 3}$ & 6 & 195 & 5904 & 21525 & 27429 \\
$\mathbf{1 9 5 4}$ & 4 & 230 & 6519 & 23379 & 29898 \\
$\mathbf{1 9 5 5}$ & 5 & 260 & 7315 & 30134 & 37449 \\
$\mathbf{1 9 5 6}$ & 8 & 290 & 7114 & 25035 & 34149 \\
$\mathbf{1 9 5 7}$ & 8 & 290 & 8187 & 31117 & 39304 \\
$\mathbf{1 9 5 8}$ & 8 & 305 & 9353 & 36377 & 45730 \\
$\mathbf{1 9 5 9}$ & 9 & 315 & 7606 & 24575 & 32181 \\
$\mathbf{1 9 6 0}$ & 12 & 350 & 9.170 & 32.176 & 41.346 \\
\hline
\end{tabular}

Kaynak: DİGM 1951-1959 ve 1960 Istatistik yıllıkları.

\footnotetext{
${ }^{7}$ Rakamlar devlet hastaneleri ve özel idareye ait hastanelerin istatistiklerinin toplamıdır. Özel idareye ait hastaneler 1947'den sonra Bakanlığa ait hastaneler arasına alınmıştır (DiGM, 1950).
} 
Posof, Çıldır ve Ardahan kazalarını dolaşan Kızılay ekibi 2 Ağustos tarihinde Selim'de çalışmalarına devam etti (Demokrat Kars Gazetesi, 2 Ağustos 1958). 11 Temmuz'dan itibaren Kars'ta faaliyet gösteren gezici hastane 400 vatandaşı muayene etti. Vasitanın gitmesine imkan olmayan yerlere atla veya yaya olarak gidildi. Muayenelerde vatandaşlara 700 penisilin, 3 kilo sülfamid, iki kiloya yakın barsak parazitleri ilacı, 1020 enjeksiyon, 1500 pansuman, 100 idrar muayenesi yapıldı. Gezici hastanenin doktorları tarafından sağlık konuları üzerinde çeşitli konferanslar verildi. Selim kazasında yapılan muayeneler sonucunda birçok vatandaşta verem olduğu tespit edildi (Ekinci Gazetesi, 2 Ağustos 1958).

Tablo 1'de 1946 ile 1960 yılları arasından Kars'ta mevcut hastaneler ve bu hastanelerde tedavi gören hastaların sayıları verilmektedir. DP iktidarında sağlık alanına yapılan yatırımın neticelerini tabloda görebilmekteyiz. İlçelerde yapılan hastane ve sağlık merkezleriyle beraber 1950 yılında 3 olan hastane sayısının 1960 yılında 12'ye yükseldiği anlaşılmaktadır.

\section{Sağlık Personeli ve Eczaneler}

Demokrat Parti döneminde Kars'ın sağlık personeli bakımından en iyi dönemi 1952 ile 1955 yılları arasıdır. 1951 yılında Kars'ta 40 doktor görev yapmaktaydı. Bunlardan 19'u asker 21'i de sivildir. Asker olarak görev yapanlardan 5'i uzman 14'ü pratisyendir. Sivil doktorlardan da 5'i uzman 16'sı da pratisyendir (DİGM, 1951). DP iktidarının sonlarına doğru, 1959 yılında, Kars'ta 23'ü uzman, 37' si pratisyen olmak üzere 60 doktor görev yapmaktadır (DİGM, 1959). Yıllara göre görev yapan doktor sayılarına bakıldığında, düzenli bir artıştan bahsedilemez. Doktor sayıları 1955 yılına kadar sürekli artarken, 1956 yılında ciddi düşüş yaşanmıştır. Sonraki yıllarda kısmi artış yaşansa da, 1960 yılında görev yapan doktor sayısı 48'e kadar düştü. Tablo 2'de de görüleceği üzere, 1950 ile 1960 yılları arasında dişçi ve hemşire sayıları, 1954 yılı hariç, belirli ortalamalarda seyretmişken, eczacı sayısı DP'nin ilk dört yıllık iktidar döneminin ardından düşüşe geçmiştir. Sağlık memuru sayılarında ise DP iktidarının son üç yıllık döneminde ciddi düşüş yaşanmıştır. Sağlık personelleri arasında düzenli olarak artan sadece ebe sayılarıdır. 10 yıllık dönemde göze çarpan 
önemli hususlardan birisi de 1954 yılının hemen hemen bütün sağlık personeli branşlarında Kars'ın en iyi durumda olduğu yıl oluşudur.

Tablo 2. DP Dönemi Kars'ta Görev Yapan Sağlık Personeli Sayılan

\begin{tabular}{cccccccc}
\hline Yıllar & $\begin{array}{c}\text { Has- } \\
\text { tane } \\
\text { Sayıs }^{8}\end{array}$ & Doktor & Dişçi & Hemşire & $\begin{array}{c}\text { Sağlık } \\
\text { Memuru }\end{array}$ & Ebe & $\begin{array}{c}\text { Ec- } \\
\text { zac1 }\end{array}$ \\
\hline $\mathbf{1 9 5 1}$ & 3 & 40 & 5 & 2 & 78 & 6 & 7 \\
$\mathbf{1 9 5 2}$ & 5 & 61 & 6 & 5 & 63 & 1 & 10 \\
$\mathbf{1 9 5 3}$ & 6 & 62 & 6 & 3 & 50 & 14 & 10 \\
$\mathbf{1 9 5 4}$ & 4 & 96 & 12 & 13 & 50 & 13 & 14 \\
$\mathbf{1 9 5 5}$ & 5 & 93 & 8 & 5 & 64 & 17 & 8 \\
$\mathbf{1 9 5 6}$ & 8 & 61 & 7 & 5 & 78 & 17 & 6 \\
$\mathbf{1 9 5 7}$ & 8 & 64 & 4 & 6 & 60 & 22 & 6 \\
$\mathbf{1 9 5 8}$ & 8 & 69 & 3 & 9 & 35 & 15 & 7 \\
$\mathbf{1 9 5 9}$ & 9 & 60 & 9 & 7 & 55 & 34 & 8 \\
$\mathbf{1 9 6 0}$ & 12 & 48 & 6 & 8 & 55 & 30 & 8 \\
\hline
\end{tabular}

Kaynak: DIGM 1950-1951, 1952 ve 1960-62 İstatistik ylllkları.

\section{Salgın Hastalıklar ve Bunlarla Mücadele}

1888 yılında 4.474 daimi ve 5.000 kadar da geçici olmak üzere toplam 9.474 nüfusu barındıran Kars şehrinde hastalıklardan ölenlerin sayısı 183 kişidir. En çok ölüm solunum yolları hastalıklarından (51 kişi) olmuştur. Ölenlerin $65^{\prime} \mathrm{i}$ bir yaşın altındaki bebekler, 49'u 1-5 yaş arası, 12' si 5-10 yaş arası çocuklar ve 17 'si de 10-25 yaş arası çocuklarla gençlerdi. Yıl içerisinde Kars şehir doktoruna toplam 867 hasta başvurmuştu. Bunların 259'u akciğer, 151'i mide ve bağırsak, 13'ü frengi, 38'i göz hastalıklarından şikâyetçiydi. 207 yatak kapasiteli Kars askeri hastanesinin 1886-88 yıllarında yapılan yeni binaları 1888'den itibaren Kars çayının kuzeyindeki Çakmak tepelerinde yer alıyordu. Binalar merkezi sıcak hava üfleme sistemi ile 1sitılıyordu. Y1l içinde hastaneye 25 subay, 1.211 asker ve zaptiye, 233 sivil olmak üzere toplam 1.469 hasta başvurmuş 59 hasta ölmüştür. En fazla bulaşıcı hastalıklar görülmüştür. O dönem vilayette askeri hastaneden başka hastane yoktur. 1888 yılında ölen 1.200 kişiden

${ }^{8}$ Verem Hastaneleri, Doğum ve Çocuk Bakım Evleri ve Sağlık Merkezleri dahil, Askeri Hastaneler hariçtir (DiGM, 1959 istatistik Yıllığı). 
525'i bir yaşın altındaki bebeklerdi. Kağızman sancağında 1.107 sıtma vakası görülmüştür. Oltu sancağında 67 frengi hastası doktora başvurmuştur. 1887 yılında bütün vilayette 4.764 çocuğa ve 1888 yılında 5.876 çocuğa çiçek aşısı yapılmıştır ve aşı başına 20 kopek $(0,2$ ruble) alınmıştır (Badem, 2010).

1935 yılında Kars Sağlık ve Sosyal Yardım Direktörlügü tarafından hazırlanan rapora göre, Kars'ta bulaşıcı hastalıklardan Frengi hastalığı çok olup, taranmadığ 2.082 hasta vardır. Cüzzam hastalığına yakalananların sayısı 1935 yılına kadar 61'dir fakat gün geçtikçe artmaktadır. Karahumma ise Kars suyunu içen halkta eksik olmamaktadır. 1934 yılında Kars'ta 67 hastalık vakası görüldü. Bu hastalıkların dişında 1934 yılı içerisinde 22 Sarısahaya, 6 Lekeli Humma, 69 Kızıl, 3 Kızamık, 5 Çiçek (Rusya'dan gelen halkta), 16 Difteri, 7 Boğmaca, 11 Kabakulak, 2 Tetanos hastalığı görüldü (BCA, 030.10.65.433.3.2.).

Salgın hastalıklar arasındaki en önemli sorunlardan olan verem hastalığıyla mücadele noktasında atılan en somut adım 1949 yılında çıkartılan Verem Savaşı Hakkında Kanun'dur. 5368 sayılı verem savaşı hakkında kanunun kabul edilmesiyle, verem savaşı dispanserleri, sağlık ocakları ve hastanelerde bu hastalıkla mücadeleye kararlı bir şekilde başlandı. Tüberküloza bağlı ölümler, 1940'lı yıllarda yılda yüz binde 150 ile 250 oranıla bütün ölüm nedenleri arasında birinci sırada yer alıyordu. Bu yüksek ölüm oranları, 1950'li yıllardan itibaren etkili ilaçların kullanılmaya başlanmasına paralel olarak, gönüllü kuruluşlarla birlikte ülke çapında uygulanan ve iyi takip edilen kontrol programı sayesinde hızla azaldı. İkinci Dünya Savaşına girmemesine rağmen, 1940'lı yıllarda ülkedeki sağlık sorunlarının artarak büyüdüğü gözlenmektedir. Bu dönemde sitma, epidemik tifüs ve çicek büyük salgınlara sebep oldu. 1945 yılında sıtma ile savaş için "Olağanüstü Sıtma Savaş Kanunu” çıarıldı (Özuğurlu, 2008).

DP iktidarı yıllarında bulaşıcı ve salgın hastalıklarla mücadele en önemli sağlık politikaları arasında yer alırken; kolera, tifüs, boğmaca, difteri ve çiçek aşısı üretilerek uygulanmaya başlandı; 1957 yılında Frengi Tedavi Yönetmeliği yayımlandı ve Cüzzam Savaş ve Araştırma Derneği (Ankara) açılarak çalışmalara başladı. Ana-çocuk sağlığına da el atılırken; 1954 yılında ana çocuk sağlığı merkezleri yapılandırılmaya başlandı, 
Atatürk Orman Çiftliği pastörize süt fabrikasının kurulmasıyla, okullarda beslenme projesi uygulandı ve devlet tarafından süt tozu dağıtılmaya başlandı ki bu çalışmada DSÖ ve UNICEF'in desteği de alınmıştır (Nesipoğlu, 2018).

16 Ekim 1950 tarihinde Ankara'da yapılan 11. Milli Tip Kongresinde devrin Sağlık ve Sosyal Hizmetler Bakanı Dr. Ekrem Hayri Üstündağ, Türkiye genelinde 40.000 kişinin veremden öldüğünü açıladı. Celal Bayar 1 Kasım 1950'de TBMM'nin açılış toplantısında sıtma, trahom, frengi ve verem gibi hastalıkların milli bünyede büyük tahribat yarattığını belirtirken, Sağlık Bakanlığı bu hastalığın aşısının tatbikini bütün memlekete yaygınlaştırma ve veremlilere ait yatak sayısını 2.000 ' den 5.000 'e çıkarma kararını aldı (Aşgın, 2000, s.166-167).

1951 nüfus istatistiğinde yer alan bilgilere göre, 1945 yılında Türkiye genelinde 25 hastalık gurubunda toplam 21.827 kişi tedavi edildi, 1.521 kişi ise öldü. 1950 yılında ise hem hastalığa yakalanma hem de ölüm oranlarında artış olduğunu görülmektedir. 280.795 kişi tedavi edilirken, 2.675 kişi de hayatını kaybetti (DİGM, 1951). Karahummadan 1945 yılında 251 kişi hayatını kaybederken, kızamıktan 334 kişi, lekeli hummadan 139 kişi ve çocuk yaz ishalinden ${ }^{9} 444$ kişi hayatını kaybetti. 1950 yılında ise çocuk yaz ishalinden ölenlerin sayısı 1.717'ye yükseldi, (DİGM, 1951). 1959 y1lında 1.258'e düştü (DİGM, 1959).

1959 yılı istatistiğinde ülke genelinde ölümlerin sebeplere göre ayrılışını incelediğimiz zaman, kızamıktan ölenlerin sayısında 9 yıllık süreçte artış olduğunu görmekteyiz. 1950 yılında kızamık hastalığından 334 kişi hayatını kaybetmişken, 1959 yılında bu rakam 461'e yükseldi. 1950'de veremden ölenlerin sayısı 1.806 iken yıldan yıla ölüm oranında düşüş yaşandı ve 1959'da 1.126'ya düştü. Ölü doğan çocuklarda ise çok ciddi bir artış söz konusudur. 1950'de ölü doğan çocuk sayısı 1.176'dır. 1959 yılında ise 4.967 'ye yükseldiğ görülmektedir. Gripten ölenlerin sayısı $25^{\prime}$ ten $218^{\prime} \mathrm{e}$ yükseldi (DİGM, 1959). İl ve ilçe merkezlerinde tüberküloza bağlı ölüm hızı 1946 yılında yüz binde 150 iken, 1960 yılında yüz binde 52'ye indi. Bebek ölüm hızında da önemli düşüşler oldu. Bebek ölüm hızı 1950 yılında binde 233 iken, 1960 yılında binde 176'ya düşürüldü. 1947 yılında Refik Saydam Hıfzıssıhha Merkezi Başkanlığı bünyesinde Biyolojik

${ }^{9}$ Çocuk yaz ishali 1946 yılında ihbarı mecburi hastalıklar arasına alındı (DiGM, 1951). 
Kontrol Laboratuvarı kuruldu ve bir aşı istasyonu hizmete açldı. Bu yıldan itibaren deri içi yolu ile uygulanan BCG aşısı üretimine geçildi. Boğmaca aşısı ise, Türkiye'de ilk olarak 1948 yılında üretilmeye başlandı (SB. Stratejik Plan 2010-2014).

1949 yılı haziran ayında Kars'ta açılan Frengi Savaş Kurulu Tuzluca ve Ardahan'da birer şube açtı. Kars'ta bu hususta ilk olarak faaliyete geçen Frengi Savaş Doktoru Abdullah Çiftçi'dir. Frengi savaş kurulunun programına göre baharın gelmesiyle beraber, köy köy, şahıs şahıs muayene edilmek suretiyle frengi hastalığına müptela vatandaşların bu istıraptan kurtarılması amaçlandı (Kars Gazetesi, 17 Aralık 1949).

Vilayet Sağlık Müdürlüğü'nün 1950 yılında bütün il çevresinde yaptırdığı tarama neticesinde 110 cüzzamlı hasta tespit edildi. Halk arasında serbestçe dolaşmakta ve yaşamakta olan bu hastaların tecrit ve tedavileri için Elazığ ve Bakırköy hastanesinden boş yatak temini istendi. Ayrıca bu hastaların nakli için lüzumlu ödeneğin verilmesi Sağlık Bakanlığı'ndan rica edildi (Kars Gazetesi, 13 Eylül 1950).

Kars Verem Savaş Derneği 1952 yılı sonunda aldığı bir kararla şehrin bütün ilkokullarındaki öğrencileri sıra ile röntgenden geçirerek, ciğerleri zayıf olan çocukları tespit etme yönünde karar aldı. Fevzi Paşa İlkokulundan başlanarak diğer okullarda da tarama yapılması kararlaştırıldı (Birlik Gazetesi, 13 Aralık 1952). 7 Ocak 1953 tarihinde verem haftası münasebetiyle açıklamalar yapan Dr. Muhtar Erengüç, Kars'la ilgili önemli verileri ortaya koymaktadır. Erengüç: “Hollanda'da vaktiyle yüz bin kişiden 300 'ü veremden ölürken bu sayı yirmi dörde düşmüştür. Amerika'da yüz bin kişide 233 olan ölüm oranı 31'e düşmüştür. Fransa'da 500'den 75'e, Almanya'da 240 'dan 72 'ye düşmüştür. Türkiye'de ise sadece Kars'ta hastaneye müracaat eden poliklinik hastaları arasında tespit edilen ise, 1942 'de 10,1946'da 51,1947'de 88,1950'de 301,1951'de ise 646 olarak kayıtlara geçmiştir. Görülüyor ki maalesef ciddi bir artış vardır. Bu rakamlar veremden vefat değil, hastalık belirtisi olanlardır. Ve şüphesiz bu oranın yüksek olması ölüm oranının da yüksek olması manasına gelecektir" dedi (Ekinci Gazetesi, 7 Ocak 1953). Konuşmasının devamında Erengüç:

"Maddi imkânsızlıklar nedeniyle veremle mücadele faaliyetleri yürütülememektedir. Röntgen makinesi olmadığı için memleket hastanesinin cihazından istifade ile işe başlayıp, Fevzi Paşa İlkokulu 
öğrencilerinin hepsini röntgenden geçirdik. Şimdiye kadar röntgenden geçirdiğimiz 310 talebeden 39'unun ciğerlerinde zafiyet tespit ettik. Yani bunlarda vereme karşı bir istidat vardır. Kendilerine gıda bakımından iyi bakmalarını ve kilo almaları gerektiğini bildirdik. Bu arada kendilerine bakamayacak fakir çocuklar varsa okul tarafından derneğimize bildirilmesi halinde derneğin kendilerine yardım yapacağını bildirdik. Sağlık Bakanlığı nezdinde verem hastanesi kurulması için teşebbüse geçtik. Fakat henüz cevap gelmedi. Üzerimize aldığımız bu mühim memleket sağlı̆̆ davasını sizlerin maddi ve manevi yardımlarına dayanarak başaracağımıza güveniyoruz. Hepiniz sevgi ve muhabbetle selamlarım" (Kars Gazetesi, 11 Ocak 1953) diyerek konuşmasını sonlandırdı.

Aynı tarihlerde Kars'ta Verem Hastanesi pansiyon binası olarak kullanılan binanın müstakil bir verem hastanesi olması için Sağlık Bakanlığı nezdinde teşebbüse geçildi (Ekinci Gazetesi, 8 Ocak 1953). Vilayet Sağlık Müdürü Hakkı Onal, Kars'ta bir Verem Dispanseri açılması için gerekli hazırlıklara başlandığını, Verem Hastanesinin de esaslı surette hizmet görebilmesini temin edecek noksanların ikmali hususunda çalışıldığını açıkladı. Sıhhat Vekaletinden gönderilen bir yazıda müsait bir bina kiralandığ1 taktirde her türlü masrafı vekalet bütçesinden karşılanmak üzere derhal bir Verem Dispanseri açılacağı bildirilmiş olduğu için, Kars Sıhhat Müdürlüğü evvela belediye nezdinde teşebbüse geçerek, dispanser için elverişli bir bina temini imkanlarını araştırdı. Bu dispanserde teşkilat kadrosuna göre bir verem mütehassısı, bir röntgen makinası ile röntgen mütehassısı, bir hemşire ve sair hizmet personeli hizmet göreceklerdir. Diğer taraftan memleket hastanesinin yanında evvelce inşa edilmiş olup, 16 hastanın yatmakta olduğu Verem Hastanesinin de esaslı suretle çalışması imkânları üzerinde duruldu (Ekinci Gazetesi, 23 Mart 1953).

Iğdır'da yaygın hastalıklarla mücadele için 1946 yılında 0,4 km, 1947 yılında 4,6 km ve 1948 yılında da 18,7 km bataklık kurutuldu (DİGM, 1950). Bölgede görev yapan sağlık personelinin de titiz çalışmaları sayesinde önemli mesafeler kat edildi. Daha önceki senelerde özellikle sıtma mücadele başkanı doktorlarından Agah Ülkü zamanında Iğdır, sıtmalı ve sivri sinekli bölge olmaktan çıkartıldı. Fakat bu doktorun Samsun'a tayinini alarak gitmesinin ardından yeri tam olarak doldurulamadi. Öyle ki Iğdır yeniden afet bölgesi halini almaya namzet duruma geldi. 
Yeni gelen genç doktorun emrindeki arabaları şehir merkezinde tutması, DDT'leri Kars'ta depo etmesi, mazot tahsisini kanun böyle diyor diyerek belediyeye yüklemeye çalışması ve buna benzer uygulamaları yüzünden halk durumu doğrudan bakanlığa bildirmek zorunda kaldı (Kars Gazetesi, 28 Temmuz 1954). Yine aynı sene Iğdır'da çiçek hastalığ görüldügüne dair orada görev yapan üç doktor tarafından verilen rapor üzerine derhal Iğdır'a hareket eden vilayet sağlık müdürü vekili ve devlet hastanesi baştabibiyle dahiliye mütehassısı, hastalığın mevcut olduğu bildirilen köye giderek hastayı muayene etti ve bunun çiçek hastalığ1 olmayıp, Pannküs denilen bir nevi cilt hastalığı olduğunu açıladı (Kars Gazetesi, 12 Ekim 1954).

\section{Sonuç}

1923 yılında Türkiye Cumhuriyeti kurulduğunda 950 yataklı 3 devlet hastanesi 635 yataklı 6 belediye hastanesi, 4.520 yataklı 45 özel idare hastanesi, 2.402 yataklı 32 özel yabancı ve azınlık hastanesi olmak üzere toplam 6.437 hasta yatağı 86 hastane bulunuyordu. Ayrıca toplamda 554 hekim, 69 eczacı, 4 hemşire, 560 sağlık memuru ve 136 ebe mevcuttu.

14 Mayıs 1950 seçimlerinin ardından Türkiye'de yönetim el değiştirdi ve 27 Mayis 1960 darbesine kadar devam edecek olan Demokrat Parti iktidarı yılları başladı. DP'li yöneticilerin ilk uygulamalarından birisi, Ankara ve İstanbul dışındaki kentlerde de halka ihtiyacı olan hizmeti daha yakınından sunabilmek için tüm kentlerde ve büyük ilçelerde hastane açma politikası izledi ve çok önemli yatırımlar yapıldı. 1950' de 118 olan toplam hastane sayısı 1960 'ta $442^{\prime}$ ye ve toplam yatak sayıs 14.581 'den $32.398^{\prime}$ e, devlet hastanesi $41^{\prime}$ den $94^{\prime}$ e ve yataklarm sayıs 7.571 'den 14.946 'ya yükseldi. Bunların haricinde sağlık merkezi, doğumevi, göğüs hastalıkları, ruh ve sinir hastalıkları, kemik hastalıkları, trahom hastanesi ve kuduz hastanelerinde de personel ve yatak sayılarında önemli artışlar yaşandı.

Ülke genelinde sağlık alanında yaşanan yatırım ve gelişmelerin olumlu etkileri Kars'a da yansıdı. 1946-1950 döneminde Sağlık Bakanlığı eliyle Kars'a yapılan kamu harcamaları 1.026.378.34 TL iken, bu rakam 19511955 döneminde 3.167.629.20 TL'ye, 1956-1960 döneminde de 9.148.339.24 TL'ye yükseldi. 1946' dan itibaren yaşanan artış, 1956-1960 arası dönemde 
üç katına yükseldi. 1946-1950 döneminde Kars'ta kişi başına düşen sağlık harcaması 2.69 TL iken, 1951-1955 döneminde bu rakam 7.72 TL'ye ve en çok harcamanın yapıldığı 1956-60 yılında ise 18.75 TL'ye yükseldi. Bu yatırımlar doğrultusunda 1950 yılında Kars vilayet sınırları içerisinde 3 olan hastane sayısı 12'ye, yatak sayısı da 115'ten 350'ye yükseldi. Diğer taraftan sağlık personeli sayısında da ciddi artışlar yaşandığı görülmektedir. Sağlık personeli sayısı da 1951 yılında toplamda 138 iken, 1960 yılında 155'e yükseldi. Ayrıca, salgın hastalıklarla mücadele noktasında şehir merkezinde ve köylerde sağlık taramaları yapılarak, hastalık tespit edilenler tedavi altına alınmaya çalışıldı. 
EXTENDED ABSTRACT

\title{
Developments In Health Care Services In The Dem- ocratic Party Era
}

\author{
İlyas Topçu
}

Kafkas University

As a result of the Treaties of Ayestefanos and Berlin signed after the Ottoman-Russian War of 1877-1878; Kars, Ardahan and Batumi were given to the Russians as war reparations. About forty years after this date, this region remained under Russian rule. At the end of World War I, when the Bolshevik revolution was in Russia, the Russians signed the Brest-Litowsk Treaty and came out of the war. Although Kars was included in the Ottoman territory with this treaty, it did not last long. On October 30, 1918, the Armistice of Mudros, signed to end the war, forced Ottoman troops to withdraw from the region. Ultimately, this land was taken back by Kazim Karabekir in 1920.

Due to sufferings at the battles, the massacres of the Armenian gangs and the difficulties of the geography; a great number of people have lost their lives and there have been too many migrations. Thus, on April 23, 1920, the newly founded Republic of Turkey was faced with serious economic difficulties. The long years of wars and the destruction of these wars had devastated the country. In particular, as mentioned above; Kars, long-suffering, the gateway of Turkey to the Caucasus, was at the bottom of the pile in every respect.

After the proclamation of the Republic, there were many problems which needed to be solved. The most serious of these issues was undoubtedly related to health. Because states' being able to maintain their existence was closely related to the health of people and society. In this direction, the government of the early Republic had started work and took important steps. But before binding up the wounds, the world was dragged into a great war again. But before the wounds had been wounded, the world was dragged into a great war again. Although Turkey had 
remained outside the World War II, it had faced the problems of the war closely.

With the end of the Great War in 1945, major changes in the world and Turkey began to experience. The end of war with the victory of the democratic block also caused the acceleration of democracy in Turkey. Turkey's need to take support of the Western block against Soviet demands over Turkish lands had also played an important role in the transition to democracy. In this direction, very serious changes and transformations began to take place in domestic politics.

On 7 January 1946, four deputies (Adnan Menderes, Celal Bayar, Fuat Köprülü and Refik Koraltan) who left the CHP formed the Democratic Party. After the election that held on May 14, 1950, the party came to power and had won three elections (1950-1954-1957 elections) until the Military Coup of May 27, 1960. During this period, significant developments took place in all areas. Health was the leading of these developments. When the significant improvements in the health field had took place in the whole of Turkey, the effects of these policies and investments had been experienced in Kars. As mentioned above, since 1877, the border city of Kars, which had faced with great battles, massacres and migrations, had been experienced great problems in the field of health as in other areas. This hospital, which was the only civilian hospital until 1950 and located in the center of Kars, had tried to serve with only two services under difficult conditions. Even the people of the region had to go to Erzurum to take X-rays.

Although there were some developments with investments made and the steps taken in the early Republican period, the health problem had an important place among the problems to be dealt with when the Democratic Party came to power. Under the leadership of Adnan Menderes, important developments took place in the field of health. The money allocated to health investments from the state budget has increased steadily over a ten-year period. As a result of these investments, the number of hospitals in Kars rose from two (when the DP came to power in 1950) to twelve after ten years of investments. In addition, the number of beds rose from 80 to 350 . Since the problem could not be solved by opening hospitals, hospitals had to provide the needs of the city in terms of health staffs. In parallel with the increase in the number of hospitals, there have been 
serious increases in the number of doctors, nurses, healthcare workers and pharmacists. But these increases were not continuous and regular. Parallel to the fluctuations in the country's economy, there were ups and downs. However, while in 1950, 9,173 people received treatment in 3 hospitals; in 1960, 41,346 people had been treated in 12 hospitals. This was a considerable number for ten years.

On the other hand, the epidemics which are the problems of the societies were also an important problem to be solved in Kars. In 1935, as stated in the report prepared by the Ministry of Health and Social Welfare, syphilis was very common in Kars. Moreover, tuberculosis, leprosy, camp fever, typhus, red fever, measles, smallpox, diphtheria, whooping-cough and mumps diseases were also prevalent. In addition to the struggles carried out until 1950, fights against all these diseases had been started in the city center and districts. In one sense, while screening in schools, the factors causing diseases had been tried to be eliminated in the meantime. The Red Crescent health teams had also been sent for health screening in places where there were not enough hospital and health center. Places, where were not possible to go by a vehicle, had been visited by riding horse or walking. Medical conferences were also given by the doctors of the mobile hospital on public health issues.

Consequently, when the Democrat Party period ended with the Military Coup of May 27, 1960; and the steps taken and the investments made during its ten-year rule had been great importance for the city. Although the health problems of Kars have not been solved in full, an important substructure has been prepared in the field of health

\section{Kaynakça / References}

Sağlık Bakanlığı. (2004). 80. Yılda Tedavi Hizmetleri (1923-2003), Tedavi Hizmetleri Genel Müdürlüğü, Ankara.

Ak, B. (2002). Türkiye cumhuriyetinde sağhlk işleri, Türkler, 17. Cilt. Ankara: Yeni Türkiye Yayınları.

Aşgın, S. (2000). Cumhuriyet döneminde doğu anadolu'ya yapılan kamu harcamaları (1946-1960). Ankara: Atatürk Araştırma Merkezi. 
Badem, C. (2010). Çarlık Rusyası yönetiminde Kars vilayeti. İstanbul: Birzamanlar Yayıncilık.

BCA, 030.10.65.433.3.1.

BCA, 030.10.65.433.3.2.

Demokrat parti tüzük ve programı (1949). (İkinci Büyük Kongrede Kabul Edilmiştir), Ankara.

DİGM, 1950 İstatistik Yıllı̆̆ı, No: 328, Cilt 18, Ankara.

DİGM, 1951 İstatistik Yıllığı, No: 332, Cilt 19, Ankara.

DİGM, 1952 İstatistik Yıllığ1, No: 342, Cilt 20, Ankara.

DİGM, 1953 İstatistik Yıllığı, No: 360, Cilt 21, Ankara.

DİGM, 1959 İstatistik Yıllığı, No: 380.

DİGM, 1960-1962 İstatistik Yıllığı, No: 460.

Gümüşçü O. (2003). Osmanlı'dan cumhuriyet'e geçiş ve cumhuriyetin ilk yıllarında Türkiye halk sağlığı, Atatürk Araştırma Merkezi Dergisi, 19(55), 125-146.

Kasapoğlu A. (2016). Türkiye'de sağlık hizmetlerinin dönüşümü. Sosyoloji Araştırmaları Dergisi, 19(2), 131-174.

Nesipoğlu, G. (2018). Olgusal bir yapı olarak sağlık politikaları: 19201960 yılları arası cumhuriyet döneminin tarihsel izleği. Hacettepe Sağllk İdaresi Dergisi, 21(1), 165-177.

Özuğurlu, S. B. (2008). 1949: Siyasal rota - halkçılık ve bağımsızlık yerine hür teşebbüsçülük ve Amerikancılık, Açıklamalı Yönetim Zamandizini 1940-1949, Ankara Üniversitesi, SBF, Ankara.

Sağlık bakanlığı, stratejik plan 2010-2014, No:778. Ankara: Sağlık Bakanlığı Yayını.

Tokatlıoğlu, İ., ve Öztürk, F. (2008). 1950-1980 Yılları arasında Türkiye'de uygulanan para ve maliye politikalarının etkinliği, Ekonomik Yaklaşım Dergisi, 19(66), 155-174.

Ural, S. (2006). Atatürk döneminde kars'ın sosyal, kültürel ve ekonomik durumu, Kars Beyaz Uykusuz Uzakta, İstanbul: Yapı Kredi Yayınları.

Birlik Gazetesi. (1952, 21 Kasım).

Birlik Gazetesi. (1952, 13 Aralık).

Demokrat Kars Gazetesi. (1958, 11 Temmuz).

Demokrat Kars Gazetesi. (1958, 2 Ağustos).

Demokrat Kars Gazetesi. (1959, 9 Mayıs).

Ekinci Gazetesi. (1953, 7 Ocak). 
Ekinci Gazetesi. (1953, 8 Ocak).

Ekinci Gazetesi. (1953, 17 Şubat).

Ekinci Gazetesi. (1953, 28 Şubat).

Ekinci Gazetesi. (1953, 23 Mart).

Ekinci Gazetesi. (1954, 14 Ocak).

Ekinci Gazetesi. (1954, 8 Temmuz).

Ekinci Gazetesi. (1955, 8 Nisan).

Ekinci Gazetesi. (1955, 18 Mayıs).

Ekinci Gazetesi. (1958, 2 Ağustos).

Kars Gazetesi. (1949, 24 Eylül).

Kars Gazetesi. (1949, 17 Aralık).

Kars Gazetesi. (1950, 1 Temmuz).

Kars Gazetesi. (1950, 13 Eylül).

Kars Gazetesi. (1952, 4 Mart).

Kars Gazetesi. (1953, 11 Ocak).

Kars Gazetesi. (1953, 23 May1s).

Kars Gazetesi. (1954, 12 Nisan).

Kars Gazetesi. (1954, 28 Temmuz).

Kars Gazetesi. (1954, 29 Eylül).

Kars Gazetesi. (1954, 12 Ekim).

Kars Gazetesi. (1956, 4 Haziran).

Kars Gazetesi. (1956, 13 Ağustos).

25.01.2019 tarihinde https://www.saglik.gov.tr/TR,11492/tarihce.html adresinden erişildi.

\section{Kaynakça Bilgisi / Citation Information}

Topçu, İ. (2019). Demokrat parti dönemi Kars'ta sağlik hizmetlerinde yaşanan gelişmeler. OPUS-Uluslararası Toplum AraştırmalarlDergisi, 11(18), 2555-2578. DOI: 10.26466/opus.525480 